\title{
Ganglioside composition of differentiated Caco-2 cells resembles human colostrum and neonatal rat intestine
}

\author{
Kareena L. Schnabl ${ }^{1}$, Catherine Field ${ }^{2}$ and M. T. Clandinin ${ }^{1,2 *}$ \\ ${ }^{1}$ Department of Medicine, University of Alberta, Edmonton, Alberta, Canada \\ ${ }^{2}$ Alberta Institute for Human Nutrition, University of Alberta, Edmonton, Alberta, Canada \\ (Received 19 October 2007 - Revised 23 May 2008 - Accepted 17 June 2008 - First published online 20 August 2008)
}

Gangliosides are glycosphingolipids found in cell membranes and human milk with important roles in cell proliferation, differentiation, growth, adhesion, migration, signalling and apoptosis. Similar changes in ganglioside composition occur during embryonic development, lactation and cancer cell differentiation. It is not known, however, whether ganglioside compositional changes that occur in differentiating colon cancer cells reflect changes that occur during intestinal development. The Caco-2 cell line is commonly used to study physiological and pathophysiological processes in the small intestine and colon. Therefore, to examine this question, undifferentiated and differentiated Caco- 2 cells were grown and total lipid was extracted from cell supernatant fractions using the Folch method. The upper aqueous phase containing gangliosides was collected and purified. Total gangliosides were measured as ganglioside-bound $\mathrm{N}$-acetyl neuraminic acid, while individual ganglioside content was quantified via a colorimetric assay for sialic acid and scanning densitometry. The total ganglioside content of differentiated Caco- 2 cells was $2 \cdot 5$ times higher compared with undifferentiated cells. Differentiated Caco-2 cells had significantly more (N-acetylneuraminyl) 2-galactosylglucosyl ceramide $\left(\mathrm{GD}_{3}\right)$ and polar gangliosides, and a lower N-acetylneuraminylgalactosylglucosylceramide $\left(\mathrm{GM}_{3}\right): \mathrm{GD}_{3}$ ratio than undifferentiated cells. The present study demonstrates that the total ganglioside content and individual ganglioside composition of differentiated Caco-2 cells are similar to those of human colostrum and neonatal rat intestine. Differentiated Caco-2 cells may therefore be an alternative model for studying physiological and pathological processes in the small intestine and colon, and may help to elucidate possible functions for specific gangliosides in development and differentiation. Further research using more sensitive techniques of ganglioside analysis is needed to confirm these findings.

Ganglioside content and composition: Caco-2 cells: Differentiation: Intestinal development: Lactation

Gangliosides, amphiphilic glycosphingolipids containing sialic acid ( $\mathrm{N}$-acetyl neuraminic acid; NANA), are found in plasma membranes of mammalian cells and are biologically important molecules involved in cell differentiation, proliferation, growth, adhesion, migration, signalling and apoptosis $^{(1-3)}$. The ganglioside composition of the brushborder membrane of the developing intestine influences patterns of bacterial colonisation and susceptibility to pathogen attachment and invasion ${ }^{(4,5)}$. Sialylated compounds have growth-promoting effects on bifidobacteria and lactobacilli, but further research is warranted to determine whether a specific ganglioside mediates the proliferative effect ${ }^{(6)}$.

In normal physiological processes such as embryogenesis and lactation ${ }^{(7)}$ and in pathological conditions including tumour onset and progression ${ }^{(8)}$, changes in ganglioside composition occur and have been shown to play significant regulatory roles. For example, melanoma cells, embryonic stem cells and human colostrum show an increase in ganglioside content and express more ( $\mathrm{N}$-acetylneuraminyl) 2-galactosylglucosyl ceramide $\left(\mathrm{GD}_{3}\right)$ than normal adult cells and mature human milk ${ }^{(9,10)}$. Moreover, the N-acetylneuraminylgalactosylglucosylceramide $\left(\mathrm{GM}_{3}\right): \mathrm{GD}_{3}$ ratio increases during development and lactation and decreases during cancer cell differentiation from highly metastatic (poorly differentiated) cancer cells to benign (highly differentiated) cells $^{(9,10)}$.

Ganglioside $\mathrm{GM}_{3}$ is an enterocyte receptor analogue for specific microbes ${ }^{(11,12)}$ and promotes cell proliferation, migration, tumorigenesis and cancer cell resistance to anticancer drug therapy ${ }^{(13-15)}$. Depending on the concentration, ganglioside $\mathrm{GD}_{3}$ exhibits a diversity of effects, such as inhibiting cell growth, inducing apoptosis, enhancing radiation and anti-cancer drug therapy efficacy and exerting anti-inflammatory effects ${ }^{(16)}$. Change in ganglioside composition relies on the balance between activities of enzymes in ganglioside biosynthetic and degradative pathways ${ }^{(9,17,18)}$. A simplified diagram of ganglioside biosynthesis and degradation is illustrated in Fig. 1.

Sialyltransferase (SAT)-1 drives lactosylceramide towards $\mathrm{GM}_{3}$ synthesis while SAT-2 catalyses the biosynthesis of

Abbreviations: EMEM, Earle's minimum essential medium; $\mathrm{GD}_{3}$, (N-acetylneuraminyl) 2-galactosylglucosyl ceramide; GM 2 , N-acetylgalactosaminyl-galactosyl(n-acetylneuraminyl)-glucosylceramide; $\mathrm{GM}_{3}$, N-acetylneuraminylgalactosylglucosylceramide; NANA, N-acetyl neuraminic acid; SAT, sialyltransferase; Tris, 2-amino-2-hydroxymethyl-propane-1,3-diol.

* Corresponding author: Dr M. T. Clandinin, fax +1 780492 8855, email tom.clandinin@ualberta.ca 


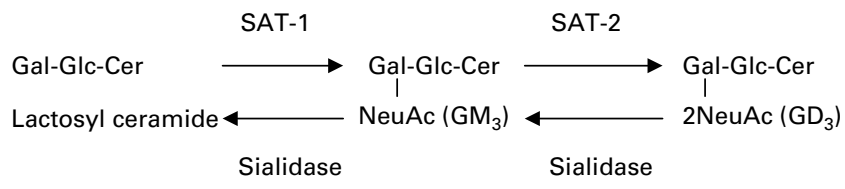

Fig. 1. Simplified schematic of ganglioside biosynthesis and degradation SAT-1, sialyltransferase 1 or $\mathrm{N}$-acetylneuraminylgalactosylglucosylceramide $\left(\mathrm{GM}_{3}\right)$ synthase; SAT-2, sialyltransferase 2 or (N-acetylneuraminyl) 2-galactosylglucosyl ceramide $\left(\mathrm{GD}_{3}\right)$ synthase; Gal, galactose; Glc, glucose; Cer, ceramide; NeuAc, $\mathrm{N}$-acetyl neuraminic acid or sialic acid.

$\mathrm{GD}_{3}$ (Fig. 1). $\mathrm{GM}_{3}$ and $\mathrm{GD}_{3}$ are desialylated by a group of enzymes called the sialidases which are classified based on their location in the cell $(1=$ lysosome, $2=$ cytosol, $3=$ plasma membrane and $4=$ mitochondria $)^{(19)}$. In a recent study, the expression of SAT-1 and SAT-2 mRNA was found to be lower in tumour tissues from patients with colorectal cancer than in corresponding healthy tissues ${ }^{(20)}$. In contrast, the expression of human plasma membrane sialidase, an enzyme involved in removing terminal sialic acid from gangliosides, was found to be up-regulated in colon cancer tissue and fetal colon ${ }^{(17)}$. Furthermore, differentiation of colon cancer cell lines (metastatic to poorly metastatic phenotype) and susceptibility to apoptosis were found to be associated with a decrease in human plasma membrane sialidase expression and activity ${ }^{(17)}$. Thus, it would be expected that a differentiating colon cancer cell would have low amounts of mitotic $\mathrm{GM}_{3}$ and high amounts of apoptotic $\mathrm{GD}_{3}$ and complex gangliosides, a ganglioside profile similar to that of human colostrum and neonatal rat intestine ${ }^{(18,21,22)}$. Despite evidence for similar changes in expression of enzymes involved in ganglioside synthesis and degradation during development, lactation and oncogenic transformation, it has not been investigated whether ganglioside compositional changes in differentiating colon cancer cells reflect changes that occur during intestine development.

Caco- 2 cells are a human colon cancer cell line isolated from a 72-year-old Caucasian male presenting with an adenocarcinoma of the colon ${ }^{(23)}$. In a study of twenty human colon tumour cell lines, Caco-2 alone showed the ability to undergo spontaneous differentiation to develop a number of characteristics more commonly associated with small-intestinal enterocytes $^{(24)}$. The development of the enterocyte-like phenotype is only evident when the cells reach confluence. During the 7-20d post-confluence differentiation time the cell monolayer gradually develops brush-border microvilli, tight junctions, cell polarity and expression of typical small-intestinal microvillus hydrolases and nutrient transporters $^{(25-27)}$. Moreover, bifidobacteria and lactobacilli species are able to adhere to Caco- 2 cells and competitively exclude enterotoxigenic Escherichia coli and Salmonella typhimurium, indicating that Caco-2 cells are a beneficial cell line for studying bacterial colonisation of the $\mathrm{gut}^{(28,29)}$. Caco-2 cells exhibit differences in polarity and expression of proteins depending on the time frame for differentiation, suggesting the potential use of Caco- 2 cells as a model for different stages of intestinal development. Obtaining sufficient amounts of infant intestine is ethically difficult and isolated primary cultures of enterocytes have a limited survival time in culture, necessitating an alternative model for neonatal intestine.
The present study was designed to determine whether differentiating Caco- 2 cells acquire a ganglioside composition profile similar to human colostrum and neonatal rat intestine, thereby resulting in a decrease in the $\mathrm{GM}_{3}: \mathrm{GD}_{3}$ ratio. The ganglioside composition of undifferentiated and differentiated Caco-2 cells has not been assessed. Considering that the Caco- 2 cell line is the most widely used cell line for studying physiological and pathophysiological processes in the small intestine and colon, understanding the change in ganglioside composition during differentiation is important to assess the potential use of differentiating Caco- 2 cells as a model for studying intestine development and paediatric intestinal disorders.

\section{Experimental methods and materials}

\section{Cell culture}

Human colon cancer Caco-2 cells (passage 44-54) were obtained from the American Type Culture Collection (ATCC, Rockville, MD, USA) and cultured in Earle's minimum essential medium (EMEM) containing $10 \%(\mathrm{v} / \mathrm{v})$ fetal bovine serum, $1 \%(\mathrm{v} / \mathrm{v})$ antibiotic/antimycotic, $26 \mathrm{mM}-$ sodium bicarbonate, $10 \mathrm{mM}$-HEPES and $1 \mathrm{mM}$-pyruvic acid. Cells were grown as adherent monolayers in $75 \mathrm{~cm}^{2} \mathrm{~T}$-flasks under standard incubator conditions (humidified atmosphere, $5 \% \mathrm{CO}_{2}, 37^{\circ} \mathrm{C}$ ) with medium replaced every $2-3 \mathrm{~d}$. Monolayers were subcultured on reaching $80-90 \%$ confluence at a split ratio of 1:3 (one T75 flask and two T150 flasks) using $0.25 \%$ trypsin-0.03\% EDTA.

For each ganglioside composition experiment, sixteen confluent T150 flasks of undifferentiated cells and four $20 \mathrm{~d}$ post-confluent T150 flasks of differentiated cells were collected in cold 2-amino-2-hydroxymethyl-propane-1,3-diol (Tris) buffer-EDTA wash using a cell scraper and were pooled together into an undifferentiated group and a differentiated group of Caco-2 cells. Cell suspensions were centrifuged for $10 \mathrm{~min}$ at $1000 \mathrm{rpm}$ and the resulting cell pellet was lysed in $0.5 \mathrm{ml}$ of $2 \mathrm{~mm}$-Tris $\mathrm{HCl}-40 \mathrm{~mm}$-mannitol lysis buffer and sonicated for $30 \mathrm{~s}$ on ice. Cell homogenates were centrifuged for $10 \mathrm{~min}$ at $12000 \mathrm{rpm}$ and cell supernatant fractions were saved for protein and ganglioside analysis.

\section{Determination of cell protein}

The amount of protein in cell supernatant fractions was determined using the bicinchoninic acid assay. Cell supernatant fractions were diluted 1 in 5 with double-distilled water. Bovine serum albumin standards and diluted cell supernatant fractions $(10 \mu \mathrm{l})$ were each mixed with $190 \mu \mathrm{l}$ of a $50: 1$ mixture of bicinchoninic acid solution and $4 \%$ (w/v) $\mathrm{CuSO}_{4} \cdot 5 \mathrm{H}_{2} \mathrm{O}$ for $30 \mathrm{~min}$ at $37^{\circ} \mathrm{C}$. The absorbance at $562 \mathrm{~nm}$ was measured with a microplate reader (Molecular Devices Corp., Sunnyvale, CA, USA).

\section{Assessment of cell differentiation markers}

Caco-2 cells were seeded on inserts in twelve-well transwell plates at a density of 400000 cells per well in $0.5 \mathrm{ml}$ EMEM-10. The bottom compartment received $1.5 \mathrm{ml}$ EMEM-10. Transepithelial resistance was measured after 
equilibration to room temperature before media change every $2-3 \mathrm{~d}$ for $30 \mathrm{~d}$ with a voltmeter to access monolayer polarity as a marker for cell differentiation. As cell polarity increases, tight junctions begin to form and the intestinal barrier becomes intact (less permeable) ${ }^{(27)}$.

Alkaline phosphatase activity of undifferentiated and differentiated Caco- 2 cells was measured as a marker of cryptvillus differentiation. Intestinal alkaline phosphatase is a brush-border enzyme expressed exclusively in villus-associated enterocytes and expression indicates the development of digestive and absorptive function ${ }^{(30)}$.

For each alkaline phosphatase activity experiment, one T150 flask each of undifferentiated (confluence) and differentiated ( $10 \mathrm{~d}$ and $20 \mathrm{~d}$ post-confluence) Caco- 2 cells was collected and cell homogenates were prepared in Tris-mannitol buffer with sonication as described previously in the cell-culture methods section. Cell homogenates and $p$-nitrophenol standards $(10 \mu \mathrm{l})$ were added to wells in a ninety-six-well plate and mixed with $190 \mu \mathrm{l}$ alkaline phosphatase reagent for $30 \mathrm{~min}$ at $37^{\circ} \mathrm{C}$. The reaction was stopped with $2 \mathrm{M}-\mathrm{NaOH}$ and the absorbance at $405 \mathrm{~nm}$ was measured with a microplate reader.

\section{Ganglioside extraction}

Total lipid was extracted from cell supernatant fractions using the Folch method ${ }^{(31)}$. In short, $0.9 \mathrm{ml}$ samples of cell supernatant fraction were mixed with $18 \mathrm{ml}$ chloroform-methanol $(2: 1, \mathrm{v} / \mathrm{v})$ and incubated overnight on a shaker. Distilled water was added to give a final ratio of $5: 1$ chloroformmethanol $(2: 1, \mathrm{v} / \mathrm{v})$-water. The upper aqueous phase containing gangliosides was collected. To increase the yield of gangliosides, the lower organic phase was washed twice with Folch upper phase solution (chloroform-methanolwater, 3:48:47, by vol.). The upper aqueous phases containing gangliosides were pooled together and purified by passage through Sep-Pak $\mathrm{C}_{18}$ cartridges (Waters Corporation, Milford, MA, USA) pre-washed with $10 \mathrm{ml}$ methanol, $20 \mathrm{ml}$ chloroform-methanol $(2: 1, \mathrm{v} / \mathrm{v})$ and $10 \mathrm{ml}$ methanol as described by Williams \& McCluer $^{(32)}$. The upper phase extract was loaded onto $\mathrm{C}_{18}$ cartridges. Cartridges were washed with $20 \mathrm{ml}$ distilled water to remove salts and water-soluble contaminants. Gangliosides were eluted with $5 \mathrm{ml}$ methanol and $20 \mathrm{ml}$ chloroform-methanol $(2: 1, \mathrm{v} / \mathrm{v})$, dried under $\mathrm{N}_{2}$ gas and redissolved in $500 \mu \mathrm{l}$ chloroform-methanol $(2: 1, \mathrm{v} / \mathrm{v})$. Gangliosides were stored at $-20^{\circ} \mathrm{C}$ until analysis.

\section{Analysis of total and individual ganglioside content}

Total gangliosides were measured as ganglioside-bound NANA as described by Suzuki ${ }^{(33)}$. A $100 \mu$ l sample of purified ganglioside sample was dried under $\mathrm{N}_{2}$ gas and dissolved with $0.5 \mathrm{ml}$ distilled water and $0.5 \mathrm{ml}$ resorcinol- $\mathrm{HCl}$ in screwcapped Teflon-lined tubes. The purple blue colour developed by heating the sample for $8 \mathrm{~min}$ at $150-160^{\circ} \mathrm{C}$ was extracted into butylacetate-butanol $(85: 15, \mathrm{v} / \mathrm{v})$ solvent. Optical density was read by a spectrophotometer (model 8452A, Hewlett Packard, Palo Alto, CA, USA) at $580 \mathrm{~nm}$. For quantitative analysis, NANA (Sigma, St Louis, MO, USA) was used as a standard.
The remaining $400 \mu \mathrm{l}$ of sample ganglioside was dried under $\mathrm{N}_{2}$ and redissolved in $100 \mu \mathrm{l}$ chloroform-methanol $(2: 1, \mathrm{v} / \mathrm{v})$. Individual gangliosides were separated by silica gel high-performance TLC (Whatman Inc., Clifton, NJ, USA) along with ganglioside standards $\mathrm{GM}_{3}, \mathrm{GD}_{3}$ and bovine brain ganglioside mixture (Alexis, San Diego, CA, USA) in a solvent system of chloroform-methanol-0.2\% (w/v) $\mathrm{CaCl}_{2} \cdot 2 \mathrm{H}_{2} \mathrm{O}$ (55:45:10, by vol.). Individual gangliosides were visualised under UV light by spraying high-performance TLC plates with $0.1 \%$ (w/v) 8-anilino-1-naphthalene-sulfonic acid. Each ganglioside band was scraped into a glass tube. Gangliosides were eluted from silica by vortex, sonication and shaking overnight in $10 \mathrm{ml}$ chloroform-methanol $(2: 1, \mathrm{v} / \mathrm{v})$. Tubes were centrifuged for $10 \mathrm{~min}$ at $1000 \mathrm{rpm}$ to spin down the silica. The chloroform-methanol $(2: 1, \mathrm{v} / \mathrm{v})$ phase was collected and combined with a $10 \mathrm{ml}$ chloroform-methanol $(2: 1, \mathrm{v} / \mathrm{v})$ wash and a $5 \mathrm{ml}$ methanol wash of the silica. Individual gangliosides were measured as ganglioside-bound NANA as described above. To determine the percentage of individual gangliosides in the mixture, gangliosides separated on high-performance TLC plates were sprayed with resorcinol- $\mathrm{HCl}$ and heated for $7-10 \mathrm{~min}$ at $150-160^{\circ} \mathrm{C}$ to visualise purple ganglioside bands. Each ganglioside band was quantified as a percentage of the total gangliosides by densitometry (Beckman CDS-200; Beckman Coulter, Mississauga, ON, Canada) using Quantity One software (Biorad Laboratories Inc., Hercules, CA, USA).

\section{Statistical analysis}

Sample size determination for a one-tailed comparison at $80 \%$ power to detect a 2-fold increase in liver gangliosides $(44.3 \mathrm{nmol} / \mathrm{g}$ wet weight to $79.1 \mathrm{nmol} / \mathrm{g}$ wet weight; $P<0.01)$ requires a sample size of three ${ }^{(34)}$. All values are displayed as mean values with their standard errors for a sample size of six (six different passages of cells) for individual gangliosides measured by the colorimetric, NANA assay, a sample size of five (five different passages of cells) for total gangliosides and a sample size of four (four different passages of cells) for individual gangliosides measured by densitometry and differentiation markers. Significant differences in amount and composition of gangliosides between undifferentiated and differentiated Caco- 2 cells were determined by a one-way ANOVA and a Tukey test with SAS statistical software (version 9.1; SAS Institute Inc., Cary, NC, USA). A $P$ value of less than 0.05 was considered statistically significant.

\section{Results}

Transepithelial resistance and alkaline phosphatase activity of undifferentiated and differentiated Caco-2 cells

Transepithelial resistance was measured when Caco-2 cells reached confluence and every $3 \mathrm{~d}$ post-confluence up to $30 \mathrm{~d}$ to monitor cell polarity as a marker of cell differentiation and development of an intact intestinal barrier. As indicated in Fig. 2 (a), transepithelial resistance displayed a linear increase over time as Caco- 2 cells differentiated. Alkaline phosphatase activity was measured when Caco- 2 cells reached confluence and 10 and $20 \mathrm{~d}$ post-confluence as a marker of crypt-villus differentiation and development of digestive 

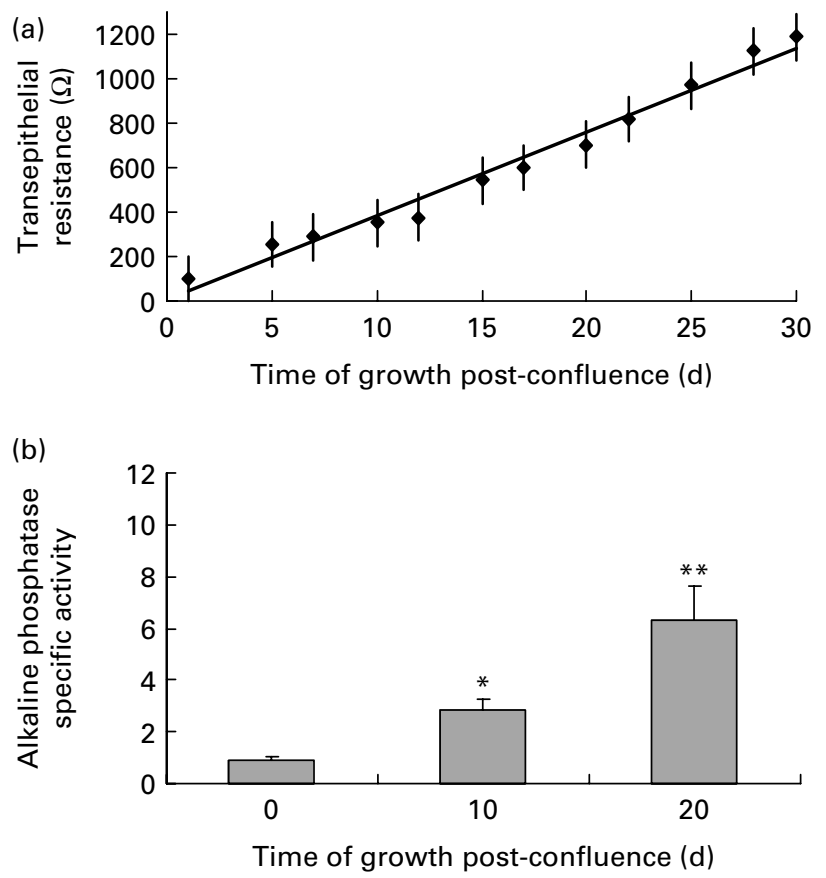

Fig. 2. Differentiation markers (a) transepithelial resistance and (b) alkaline phosphatase specific activity for Caco-2 cells measured at confluence (undifferentiated cells) and post-confluence (differentiated cells). Values are means for a sample size of four (four different cell passages), with standard errors represented by vertical bars. Mean value was significantly different from that at confluence: ${ }^{\star} P<0.001,{ }^{\star \star} P \leq 0.0001$.

and absorptive function. As indicated in Fig. 2 (b), alkaline phosphatase activity was significantly higher 10 and $20 \mathrm{~d}$ post-confluence compared with undifferentiated, confluent Caco-2 cells.

\section{Total ganglioside content of undifferentiated and differentiated Caco-2 cells}

The influence of differentiation on total ganglioside content of human colon cancer Caco-2 cells is shown in Fig. 3. Caco-2 cells differentiated for $20 \mathrm{~d}$ had 2.5 times higher ganglioside content compared with undifferentiated Caco- 2 cells.

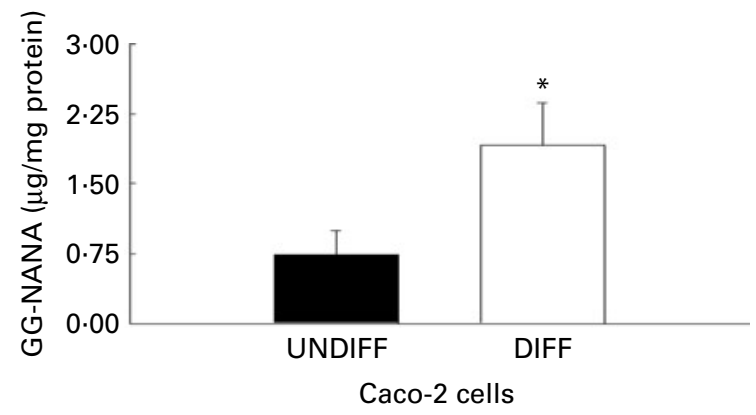

Fig. 3. Total content of ganglioside-bound $\mathrm{N}$-acetyl neuraminic acid (GG-NANA) in undifferentiated (UNDIFF) and differentiated (DIFF) human colon cancer Caco-2 cells grown to confluence or differentiated $20 \mathrm{~d}$ postconfluence, respectively. Values are means for a sample size of five (five different cell passages), with standard errors represented by vertical bars. * Mean value was significantly different from that of the undifferentiated cells $(P<0.05)$.
Quantification of individual ganglioside composition in undifferentiated and differentiated human colon cancer Caco-2 cells

The amounts and percentages of individual gangliosides as well as changes in the $\mathrm{GM}_{3}: \mathrm{GD}_{3}$ ratio of undifferentiated and differentiated Caco- 2 cells measured using a colorimetric NANA assay and scanning densitometry are illustrated (Fig. 4). Differentiated Caco-2 cells had a significantly higher amount of $\mathrm{GD}_{3}$ and polar gangliosides and a trend towards lower amounts of $\mathrm{GM}_{3}$ compared with undifferentiated cells (Fig. 4 (a)). Moreover, the percentage $\mathrm{GD}_{3}$ and polar gangliosides was also significantly higher in differentiated cells (Fig. 4 (b)). Undifferentiated cells had a higher percentage of $\mathrm{GM}_{3}$ and $\mathrm{N}$-acetylgalactosaminyl-galactosyl(n-acetylneuraminyl)-glucosylceramide $\left(\mathrm{GM}_{2}\right)$ (Fig. 4 (b)). Independent of the method used to quantify individual gangliosides, the $\mathrm{GM}_{3}: \mathrm{GD}_{3}$ ratio decreased when Caco-2 cells were differentiated and the drop in the ratio was significant when gangliosides were quantified using the NANA assay (Fig. 4 (a) and (b)).

\section{Discussion}

The discovery that changes in glycosphingolipid metabolism are similar during development and oncogenic transformation
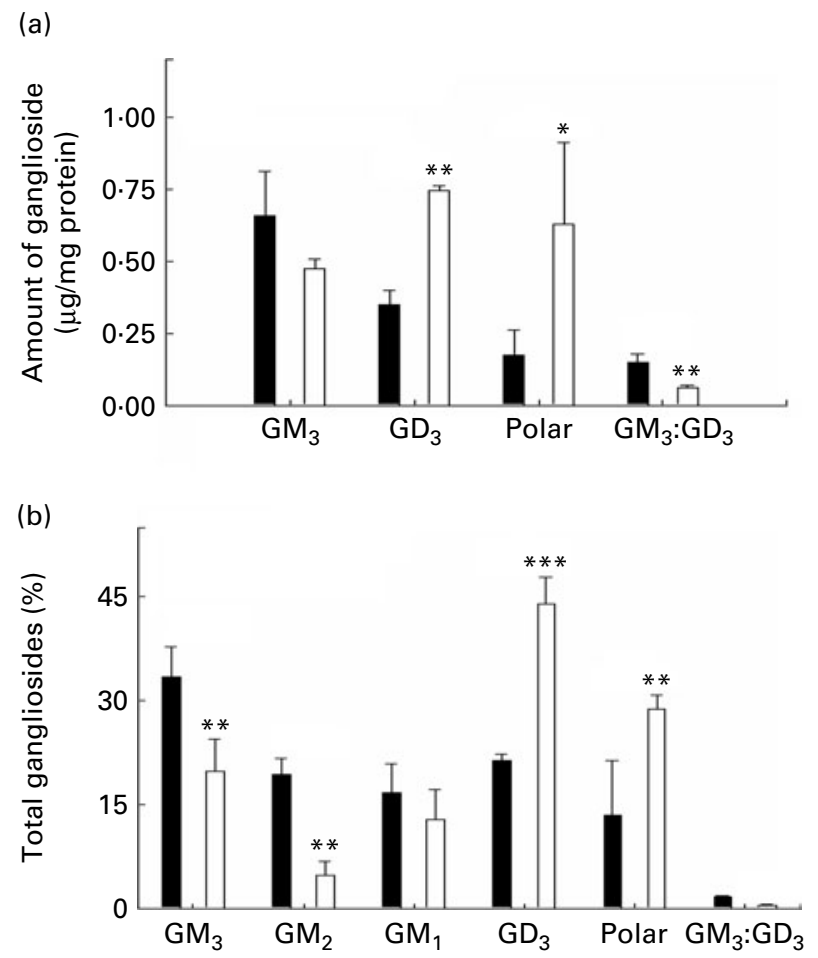

Fig. 4. Ganglioside composition of undifferentiated ( $\square$ ) and differentiated ( $\square$ ) Caco- 2 cells measured by a colorimetric $\mathrm{N}$-acetyl neuraminic acid assay (a) and scanning densitometry (b). $\mathrm{GM}_{3}, \mathrm{~N}$-acetylneuraminylgalactosylglucosylceramide; $\mathrm{GD}_{3}$, (N-acetylneuraminyl) 2-galactosylglucosyl ceramide; $\mathrm{GM}_{2}$, $\mathrm{N}$-acetylgalactosaminyl-galactosyl-(n-acetylneuraminyl)-glucosylceramide; $\mathrm{GM}_{1}$, galactosyl-n-acetylgalactosaminyl-(n-acetylneuraminyl)-galactosyl-glucosylceramide. Values are means for a sample size of six (six different cell passages), with standard errors represented by vertical bars. Mean value was significantly different from that of the undifferentiated cells: ${ }^{\star} P<0.01,{ }^{\star *} P \leq 0.005$, ${ }^{* * *} P \leq 0.0001$. 
prompted research on the characterisation of ganglioside content and composition during different stages of cell differentiation. Differentiating nerve and leukaemia cell lines have been investigated thoroughly; however, knowledge on the ganglioside content and composition of differentiating intestinal cells is limited ${ }^{(13,35)}$. With increasing evidence that parallel changes in ganglioside content and composition occur during lactation and intestinal development ${ }^{(9,18,22)}$, it became of interest to investigate whether ganglioside alterations during intestinal cancer cell differentiation resemble the compositional changes during lactation and intestinal development. A comparable shift in ganglioside content and composition would demonstrate the potential use of differentiating Caco- 2 cells as a model for studying the physiology and pathophysiology of the neonatal gut.

The present study investigated the ganglioside content and composition of undifferentiated and differentiated human colon cancer Caco- 2 cells. The study demonstrated that differentiated human colon cancer Caco- 2 cells have 2.5 times more total gangliosides than poorly differentiated Caco- 2 cells. The trend for enhanced ganglioside content following differentiation is supported by the observation that ganglioside sugar-chain elongation is enhanced in differentiated human colon cancer HT-29 cells $^{(36)}$. Moreover, lipid-bound sialic acid levels are significantly elevated in hepatoma tissues during proliferation and differentiation ${ }^{(37)}$. Similar to differentiated colon cancer cells, human colostrum has twice as many gangliosides as mature milk and a larger fraction of complex gangliosides with branched sugar chains ${ }^{(18)}$. Although the ganglioside content of the infant bowel has not been investigated, it is known that neonatal rat intestine contains more gangliosides than adult rat intestine and that the ganglioside composition varies along the crypt-villus axis $^{(21,38)}$. Recently, acidic milk oligosaccharides, some of which are precursors for the synthesis of gangliosides, were demonstrated to inhibit Caco- 2 cell growth and induce differentiation at concentrations 100 -fold higher than the concentration of gangliosides present in human milk, and known to be effective in down-regulating the inflammatory response ${ }^{(39)}$. The accumulation of individual gangliosides in colostrum, immature intestine and differentiated intestinal cells suggests a unique physiological role for specific gangliosides in cell development and differentiation.

Individual ganglioside composition of undifferentiated and differentiated Caco- 2 cells was determined and compared with human colostrum and immature rat intestine to elucidate possible functions for specific gangliosides in development and differentiation. The effect of gangliosides on proliferation and migration are differential and depend on cell type and ganglioside-associated molecules in the individual cell types ${ }^{(40)}$. In the present study, ganglioside accumulation in differentiated Caco-2 cells was accompanied by changes in the individual ganglioside composition. Differentiated Caco-2 cells contained more $\mathrm{GD}_{3}$ and polar, complex gangliosides than undifferentiated Caco- 2 cells. Human colostrum and differentiated human embryonic stem cells also contain high amounts of $\mathrm{GD}_{3}$ and polar, complex gangliosides ${ }^{(22,41)} \cdot \mathrm{GD}_{3}$ and polar gangliosides may play a role in tight-junction formation (EJ Park, ABR Thomson and MT Clandinin, unpublished results), intestinal barrier integrity and the expression of proteins involved in digestion and absorption ${ }^{(42,43)}$.
The accumulation of $\mathrm{GD}_{3}$ and polar gangliosides in colostrum, differentiated stem cells and differentiated colon cancer cells may support a role for $\mathrm{GD}_{3}$ and polar gangliosides in promoting intestinal development and enterocyte differentiation. In Caco- 2 cells, Ca-sensing receptors that regulate cell proliferation and are modulated by gangliosides are most concentrated in crypt cells and differentiated colon cancer lesions ${ }^{(44)}$. Accumulation of $\mathrm{GM}_{3}, \mathrm{GD}_{3}$ and polar gangliosides in cells with receptors that regulate cell proliferation and growth suggests a role for $\mathrm{GM}_{3}, \mathrm{GD}_{3}$ and polar gangliosides in regulating cell proliferation during development, intestinal reconstitution and tumour progression. Perhaps the relative amount of each molecular species of ganglioside determines the balance between proliferation and apoptosis.

Differentiated Caco- 2 cells also contained a relatively lower percentage of $\mathrm{GM}_{3}$ when compared with undifferentiated Caco-2 cells. This ganglioside compositional change was accompanied by a small decrease in the $\mathrm{GM}_{3}: \mathrm{GD}_{3}$ ratio. Nojiri demonstrated that differentiated HCT-116 colon cancer cells lose tumorigenic activity and become susceptible to apoptosis by artificially increasing $\mathrm{GM}_{3}$ content ${ }^{(45)}$. Differentiated leukaemia cells and macrophages have been shown to have elevated levels of $\mathrm{GM}_{3}^{(46,47)}$. Unlike some other differentiated cell lines, the differentiated Caco- 2 cell did not have a significantly different $\mathrm{GM}_{3}$ content from that of the undifferentiated form. The intestinal barrier has a unique role in protecting the host from the external environment from birth through to adult life and undergoes frequent cell turnover. The presence of $\mathrm{GM}_{3}$ in undifferentiated Caco-2 cells may be important for cell proliferation and renewal while $\mathrm{GM}_{3}$ enrichment in the villi as observed in neonatal rat intestine may be important for regulating bacteria colonisation and protection against microbe invasion ${ }^{(38)}$. The differentiated Caco- 2 cell also had a lower percentage of $\mathrm{GM}_{3}$ and $\mathrm{GM}_{2}$. Thus, the decrease in the $\mathrm{GM}_{3}: \mathrm{GD}_{3}$ ratio is attributed to an increase in $\mathrm{GD}_{3}$ content with a small decline in $\mathrm{GM}_{3}$. Perhaps differentiating Caco-2 cells up-regulate SAT-2 and convert $\mathrm{GM}_{3}$ into $\mathrm{GD}_{3}$ with hydrolysis of $\mathrm{GM}_{2}$ replenishing some of the lost $\mathrm{GM}_{3}$. Several studies have observed an elevation in the $\mathrm{GD}_{3}$ synthesis level of apoptotic cells ${ }^{(48-50)}$. Saha demonstrated that the level of $\mathrm{GM}_{2}$ and $\mathrm{GM}_{3}$ correlates with metastatic potential $^{(51)}$. Furthermore, differentiation of colon cancer cell lines (metastatic to poorly metastatic phenotype) and susceptibility to apoptosis was found to be associated with a decrease in human plasma membrane sialidase expression and activity ${ }^{(17)}$. Taken together with previous studies, the susceptibility of differentiated Caco- 2 cells to apoptosis may be explained by elevated apoptotic $\mathrm{GD}_{3}$ while malignancy may be promoted by suppressing apoptosis through hydrolysis of $\mathrm{GD}_{3}$.

The difference in the $\mathrm{GM}_{3}: \mathrm{GD}_{3}$ ratio between undifferentiated and differentiated Caco- 2 cells was small in comparison with the large changes reported in the literature during lactation. Depending on the ganglioside analysis method, undifferentiated Caco-2 cells had a $\mathrm{GM}_{3}: \mathrm{GD}_{3}$ ratio that was $2 \cdot 4-3 \cdot 5$ times higher than the $\mathrm{GM}_{3}: \mathrm{GD}_{3}$ ratio of differentiated Caco2 cells. In a study that followed the change in ganglioside composition of human milk over time, the $\mathrm{GM}_{3}: \mathrm{GD}_{3}$ ratio was reported to be seventy times greater in mature milk when compared with colostrum (0.05 colostrum $v$. 3.5 mature milk) ${ }^{(52)}$. The shift in the ratio during lactation was 
associated with a large increase in $\mathrm{GM}_{3}$ levels along with a large decrease in $\mathrm{GD}_{3}$ levels ${ }^{(18)}$. The $\mathrm{GM}_{3}: \mathrm{GD}_{3}$ ratio of mature rat small intestine is 26 , similar to the ratio of 19.8 observed in mature milk ${ }^{(18,53)}$. For neonatal rat small intestine, the $\mathrm{GM}_{3}: \mathrm{GD}_{3}$ ratio has not been determined; however, it is known that neonatal tissues decrease in $\mathrm{GD}_{3}$ content and increase in $\mathrm{GM}_{3}$ content during development ${ }^{(21,22,41)}$. Although the ganglioside composition changes are similar during rat intestine development, lactation and oncogenic transformation of colon cells, further ganglioside analysis work should be completed with infant bowel to determine changes in the $\mathrm{GM}_{3}: \mathrm{GD}_{3}$ ratio during development and look at the degree of change in $\mathrm{GM}_{3}$ and $\mathrm{GD}_{3}$ levels. The changes in ganglioside content and composition of Caco- 2 cells should also be measured in partially differentiated Caco- 2 cells and confirmed with a more sensitive ganglioside analysis method such as liquid chromatography-tandem MS to more accurately access individual ganglioside composition ${ }^{(54)}$. Adapting a more sensitive ganglioside analysis method would decrease tissue requirements, eliminate cell pooling and help clarify the changes that occur in individual species of polar, complex gangliosides that are often present in small amounts.

In summary, differentiated Caco- 2 cells have a much higher ganglioside content than undifferentiated cells, including significantly greater $\mathrm{GD}_{3}$ and polar gangliosides and a trend towards lower levels of $\mathrm{GM}_{3}$. An accumulation of $\mathrm{GD}_{3}$ and polar gangliosides in colostrum, differentiated stem cells and differentiated colon cancer cells may support a role for $\mathrm{GD}_{3}$ and polar gangliosides in promoting intestinal development and enterocyte differentiation. Differences in the $\mathrm{GM}_{3}: \mathrm{GD}_{3}$ ratio between undifferentiated and differentiated Caco-2 cells were small in comparison with the large changes observed by others during lactation; therefore future studies should employ more sensitive techniques of ganglioside analysis to confirm these findings. These preliminary results suggest that differentiated Caco- 2 cells may be an alternative model for studying physiological and pathological processes in the small intestine and colon, and may help to elucidate possible functions for specific gangliosides in development and differentiation.

\section{Acknowledgements}

The present study was supported by a Canadian Institute of Health research grant and a National Sciences and Engineering Research Council scholarship.

The present study was K. L. S.'s research thesis; C. F. contributed to the study's methodology and interpretation; M. T. C. was the principal investigator and supervisor.

There are no conflicts of interest in respect of this paper.

\section{References}

1. Hakomori S (1990) Bifunctional role of glycosphingolipids. Modulators for transmembrane signaling and mediators for cellular interactions. J Biol Chem 265, 18713-18716.

2. Ledeen RW (1989) Biosynthesis, metabolism and biological effects of gangliosides. In Neurobiology of Glycoconjugates, pp. 43-48 [RU Margolis and RK Margolis, editors]. New York: Plenum Press.
3. Merrill AH Jr, Schmelz EM, Dillehay DL, Spiegel S, Shayman JA, Schroeder JJ, Riley RT, Voss KA \& Wang E (1997) Sphingolipids - the enigmatic lipid class: biochemistry, physiology, and pathophysiology. Toxicol Appl Pharmacol 142, 208-225.

4. Mukai T, Kaneko S, Matsumoto M \& Ohori H (2004) Binding of Bifidobacterium bifidum and Lactobacillus reuteri to the carbohydrate moieties of intestinal glycolipids recognized by groundnut agglutinin. Int J Food Microbiol 90, 357-362.

5. Fantini J, Maresca M, Hammache D, Yahi N \& Delezay O (2000) Glycosphingolipid (GSL) microdomains as attachment platforms for host pathogens and their toxins on intestinal epithelial cells: activation of signal transduction pathways and perturbations of intestinal absorption and secretion. Glycoconj $J$ 17, 173-179.

6. Nakano T, Sugawara M \& Kawakami H (2001) Sialic acid in human milk: composition and functions. Acta Paediatr Taiwan 42, 11-17.

7. Yamashita T, Wada R, Sasaki T, Deng C, Bierfreund U, Sandhoff K \& Proia RL (1999) A vital role for glycosphingolipid synthesis during development and differentiation. Proc Natl Acad Sci U S A 96, 9142-9147.

8. Hakomori S (1996) Tumor malignancy defined by aberrant glycosylation and sphingo(glyco)lipid metabolism. Cancer Res 56, 5309-5318.

9. Draper JS, Pigott C, Thomson JA \& Andrews PW (2002) Surface antigens of human embryonic stem cells: changes upon differentiation in culture. J Anat 200, 249-258.

10. Ravindranath MH, Tsuchida T, Morton DL \& Irie RF (1991) Ganglioside $\mathrm{GM}_{3}: \mathrm{GD}_{3}$ ratio as an index for the management of melanoma. Cancer 67, 3029-3035.

11. Kyogashima M, Ginsburg V \& Krivan HC (1989) Escherichia coli K99 binds to $N$-glycolylsialoparagloboside and $N$-glycolyl-GM $\mathrm{GM}_{3}$ found in piglet small intestine. Arch Biochem Biophys 270, 391-397.

12. Rolsma MD, Kuhlenschmidt TB, Gelberg HB \& Kuhlenschmidt MS (1998) Structure and function of a ganglioside receptor for porcine rotavirus. J Virol 72, 9079-9091.

13. Noguchi M, Kabayama K, Uemura S, Kang BW, Saito M, Igarashi Y \& Inokuchi J (2006) Endogenously produced ganglioside $\mathrm{GM}_{3}$ endows etoposide and doxorubicin resistance by up-regulating Bcl-2 expression in 3LL Lewis lung carcinoma cells. Glycobiology 16, 641-650.

14. Saha S, Mohanty KC \& Mallick P (2005) Gangliosides enhance migration of mouse B16-melanoma cells through artificial basement membrane alone or in presence of laminin or fibronectin. Indian J Exp Biol 43, 1130-1138.

15. Wang JH, Huang ZM, Wu JS, Chen XR, Jin SQ, Huang QK \& Wang D (2006) Ganglioside $\mathrm{GD}_{3}$ enhances the anti-tumor effect of doxorubicin on hepatoma cells (article in Chinese). Zhonghua Gan Zang Bing Za Zhi 14, 710-711.

16. Malisan F \& Testi $\mathrm{R}$ (2005) The ganglioside $\mathrm{GD}_{3}$ as the Greek goddess Hecate: several faces turned towards as many directions. IUBMB Life 57, 477-482.

17. Kakugawa Y, Wada T, Yamaguchi K, Yamanami H, Ouchi K, Sato I \& Miyagi T (2002) Up-regulation of plasma membraneassociated ganglioside sialidase (Neu3) in human colon cancer and its involvement in apoptosis suppression. Proc Natl Acad Sci U S A 99, 10718-10723.

18. Takamizawa K, Iwamori M, Mutai M \& Nagai Y (1986) Selective changes in gangliosides of human milk during lactation: a molecular indicator for the period of lactation. Biochim Biophys Acta 879, 73-77.

19. Yamanami H, Shiozaki K, Wada T, Yamaguchi K, Uemura T, Kakugawa Y, Hujiya T \& Miyagi T (2007) Down-regulation of sialidase NEU4 may contribute to invasive properties of human colon cancers. Cancer Sci 98, 299-307. 
20. Gornati R, Chini V, Rimoldi S, Meregalli M, Schiaffino E \& Bernardini G (2007) Evaluation of SAT-1, SAT-2 and GalNAcT-1 mRNA in colon cancer by real-time PCR. Mol Cell Biochem 298, 59-68.

21. Bouhours JF, Bouhours D \& Hansson GC (1993) Developmental changes of glycosphingolipid composition of epithelia of rat digestive tract. Adv Lipid Res 26, 353-372.

22. Rueda R, Maldonado J, Narbona E \& Gil A (1998) Neonatal dietary gangliosides. Early Hum Dev 53, S135-S147.

23. Fogh J, Fogh JM \& Orfeo T (1977) One hundred and twentyseven cultured human tumor cell lines producing tumors in nude mice. J Natl Cancer Inst 59, 221-226.

24. Chantret I, Barbat A, Dussaulx E, Brattain MG \& Zweibaum A (1988) Epithelial polarity, villin expression, and enterocytic differentiation of cultured human colon carcinoma cells a survey of twenty cell lines. Cancer Res 48, 1936-1942.

25. Chantret I, Rodolosse A, Barbat A, Dussaulx E, Brot-Laroche E, Zweibaum A \& Rousset M (1994) Differential expression of sucrase-isomaltase in clones isolated from early and late passages of the cell line Caco-2, evidence for glucose-dependent negative regulation. J Cell Sci 107, 213-225.

26. Harris DS, Slot JW, Geuze HJ \& James DE (1992) Polarized distribution of glucose transporter isoforms in Caco-2 cells. Proc Natl Acad Sci U S A 89, 7556-7560.

27. Peterson MD, Bement WM \& Mooseker MS (1993) An in vitro model for the analysis of intestinal brush border assembly. II. Changes in expression and localization of brush border proteins during cell contact-induced brush border assembly in Caco2BBe cells. J Cell Sci 105, 461-472.

28. Bernet MF, Brassart D, Neeser JR \& Servin AL (1993) Adhesion of human bifidobacterial strains to cultured human intestinal epithelial cells and inhibition of enteropathogen-cell interactions. Appl Environ Microbiol 59, 4121-4128.

29. Duffy LC (2000) Interactions mediating bacterial translocation in the immature intestine. J Nutr 130, 432S-436S.

30. Goldberg RF, Austen WG Jr, Zhang X, et al. (2008) Intestinal alkaline phosphatase is a gut mucosal defense factor maintained by enteral nutrition. Proc Acad Natl Sci U S A 105, 3551-3556.

31. Folch J, Lees M \& Sloane Stanley GH (1957) A simple method for the isolation and purification of total lipides from animal tissues. J Biol Chem 226, 497-509.

32. Williams MA \& McCluer RH (1980) The use of Sep-Pak C18 cartridges during the isolation of gangliosides. $J$ Neurochem 35, 266-269.

33. Suzuki Y, Suzuki N, Michi H \& Matsumoto M (1985) Characterization of gangliosides of porcine erythrocyte membranes: occurrence of ganglioside $\mathrm{GD}_{3}$ as major ganglioside. Lipids 20, 588-593.

34. Majer F, Trnka L, Vítek L, Jirkovská M, Marecek Z \& Smíd F (2007) Estrogen-induced cholestasis results in a dramatic increase of b-series gangliosides in the rat liver. Biomed Chromatogr 21, 446-450.

35. Varner JA (2007) Stem cells and neurogenesis in tumors. Prog Exp Tumour Res 39, 122-129.

36. Houri JJ, Falbo A, Vignali G, Codogno P \& Ghidoni R (1994) The metabolic processing of glycosphingolipids in HT-29 cells is differentiation-dependent. Biochem Biophys Res Commun 202, 992-1000.

37. Lu CQ, Lu J, Wang BL \& Cui YZ (2000) Changes in ganglioside contents, plasma sialic acid and cAMP levels in experimental hepatoma in mice. Mol Cell Biochem 207, 29-33.

38. Glickman RM \& Bouhours JF (1976) Characterization, distribution and biosynthesis of the major ganglioside of rat intestinal mucosa. Biochim Biophys Acta 424, 17-25.
39. Kuntz S, Rudloff S \& Kunz C (2008) Oligosaccharides from human milk influence growth-related characteristics of intestinally transformed and non-transformed cells. J Nutr 99, $462-471$.

40. Kamimura Y, Furukawa K, Kittaka D, Nishio M, Hamamura K, Fukumoto S \& Furukawa K (2005) Differential enhancing effects of $\alpha 2,8$-sialyltransferase on the cell proliferation and mobility. Int J Oncol 26, 337-344.

41. Kwak DH, Yu K, Kim SM, et al. (2006) Dynamic changes of gangliosides expression during the differentiation of embryonic and mesenchymal stem cells into neural cells. Exp Mol Med 38, 668-676.

42. Drozdowski LA, Suh M, Park E, Clandinin MT \& Thomson AB (2007) Dietary gangliosides enhance in vitro glucose uptake in weanling rats. J Parenter Enteral Nutr 31, 423-429.

43. Birecki CJ, Drozdowski LA, Suh M, Park EJ, Clandinin MT \& Thomson AB (2006) Dietary gangliosides enhance in vitro lipid uptake in weanling rats. J Pediatr Gastroenterol Nutr 42, $59-65$.

44. Kállay E, Bajna E, Wrba F, Kriwanek S, Peterlik M \& Cross HS (2000) Dietary calcium and growth modulation of human colon cancer cells: role of the extracellular calcium-sensing receptor. Cancer Detect Prev 24, 127-136.

45. Nojiri H, Yamana H, Shirouzu G, Suzuki T \& Isono H (2002) Glycotherapy for cancer: remodeling of ganglioside pattern as an effective approach for cancer therapy. Cancer Detect Prev 26, 114-120.

46. Chung TW, Choi HJ, Lee YC \& Kim CH (2005) Molecular mechanism for transcriptional activation of ganglioside $\mathrm{GM}_{3}$ synthase and its function in differentiation of HL-60 cells. Glycobiology 15, 233-244.

47. Nojiri H, Takaku F, Terui Y, Miura Y \& Saito M (1986) Ganglioside $\mathrm{GM}_{3}$, an acidic membrane component that increases during macrophage-like cell differentiation can induce monocytic differentiation of human myeloid and monocytoid leukemic cell lines HL-60 and U937. Proc Acad Natl Sci U S A 83, $782-786$.

48. Bennaceur K, Popa I, Portoukalian J, Berthier-Vergnes O \& Peguet-Navarro J (2006) Melanoma-derived gangliosides impair migratory and antigen-presenting function of human epidermal Langerhans cells and induce their apoptosis. Int Immunol 18, 879-886.

49. Hasegawa T, Sugeno N, Takeda A, Matsuzaki-Kobayashi M, Kikuchi A, Furukawa K, Miyagi T \& Itoyama Y (2007) Role of Neu4L sialidase and its substrate ganglioside $\mathrm{GD}_{3}$ in neuronal apoptosis induced by catechol metabolites. FEBS Lett 581, 406-412.

50. Omran OM, Saqr HE \& Yates AJ (2006) Molecular mechanisms of $\mathrm{GD}_{3}$-induced apoptosis in U-1242 MG glioma cells. Neurochem Res 31, 1171-1180.

51. Saha S \& Mohanty KC (2003) Correlation of gangliosides $\mathrm{GM}_{2}$ and $\mathrm{GM}_{3}$ with metastatic potential to lungs of mouse B16 melanoma. J Exp Clin Cancer Res 22, 125-134.

52. Pan XL \& Izumi T (1999) Chronological changes in the ganglioside composition of human milk during lactation. Early Hum Dev 55, 1-8.

53. Park EJ, Suh M, Ramanujam K, Steiner K, Begg D \& Clandinin MT (2005) Diet-induced changes in membrane gangliosides in rat intestinal mucosa, plasma and brain. J Pediatr Gastroenterol Nutr 40, 487-495.

54. Sorensen LK (2006) A liquid chromatography/tandem mass spectrometric approach for the determination of gangliosides $\mathrm{GD}_{3}$ and $\mathrm{GM}_{3}$ in bovine milk and infant formulae. Rapid Commun Mass Spectrom 20, 3625-3633. 